\title{
АВТОМАТИЗОВАНА ПОБУДОВА МОДЕЛЕЙ ПРОГНОЗУВАННЯ ЗБУТУ ХЛІБОБУЛОЧНИХ ВИРОБІВ
}

\author{
Жигайло О.М. ${ }^{1}$, Топор М.М. ${ }^{2}$ \\ Одеська національна академія харчових технологій, Одеса, Україна \\ ORCID: ${ }^{10000-0001-6986-4673, ~}{ }^{2} 0000-0002-0779-1816$ \\ E-mail: 1d_jam2006@ukr.net, ㄹiicklv@gmail.com
}

Copyright (C) 2018 by author and the journal "Automation technologies and business - processes. This work is licensed under the Creative Commons Attribution International License (CC BY). http://creativecommons.org/licanses/by/4.0
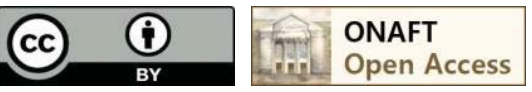

DOI:

\begin{abstract}
Анотація: Дослідження процесів збуту та планування виробництва є важливою складовою діяльності будь-якого комериійного підприємства. Це пояснюється тим, щзо професійне вирішення основних задач збуту обумовлює максимальний рівень задоволення потреби клієнтів, створення додаткових маркетингових переваг, збільшення обсягів реалізації, забезпечення зростання прибутку не тільки в коротко, але $i$ в довгостроковому періоді. Для підвищення ефективності управління прочесами збуту та планування виробництва сучасні підприємства використовують різноманітні програмні продукти, які автоматизують тільки частину їх бізнес-процесів. В тих продуктах, які займаються аналізом, прогнозуванням збуту та плануванням виробництва, існують проблеми з рівнем точності результатів прогнозу. Тому розробка програмних модулів, щзо спрощують вирішення задачі прогнозування та підвищують точність отриманих результатів є досить актуальною. Для вирішення задачі прогнозування була обрана модель проінтегрованої авторегресї та ковзного середнього (АRIMA). Перед побудовою моделей прогнозування проводиться автоматична класифікація (кластеризація) досліджуваних часових рядів для виявлення чітких груп зі схожими властивостями, яка надає можливість вибору початкової структури моделей прогнозування для кожної із груп. Після иъього йде валідачія або корегування значень порядку складових моделей (AR, MA), завдяки результатам обробки коррелограмм автокореляційної та приватної автокореляційної функій. На останньому етапі за допомогою методу найменших квадратів розраховуються параметри сформованих моделей прогнозування.

Abstract: Research of sales processes and production planning is an important part of any commercial enterprise. This is explained by the fact that the professional solution of the main sales objectives determines the maximum level of customers' satisfaction, creating additional marketing benefits, increasing sales, ensuring profit growth not only in short but also in the long term period. In order to increase the effectiveness of managing sales processes and production planning, modern enterprises use a variety of software products that automate only part of their business processes in different ways. In products that analyze, forecast sales and production planning, there are problems with the level of accuracy of the results of the forecast. Therefore, the development of software modules that simplify the task of forecasting and increase the accuracy of the results obtained is very relevant. In order to solve the problem of forecasting, the model of integrated auto regression and moving average (ARIMA) was chosen. Before the construction of prediction models, an automatic classification (clustering) of the studied time series is conducted to identify distinct groups with similar properties, which gives the opportunity to choose the initial structure of forecasting models for each group. After that, the validation or correction of the values of the order of component models (AR, MA) is followed, due to the results of processing correlograms autocorrelation and private autocorrelation function. At the last stage, using the least squares method, the parameters of the generated forecasting models are calculated.
\end{abstract}

Ключові слова: прогнозування збуту, планування виробництва, хлібобулочні вироби, програмний модуль, кореляційна функція, модель прогнозування.

Key words: sales forecasting, production planning, bakery products, software module, correlation function, forecasting model.

Вступ. Всі сучасні підприємства мають велику кількість різноманітних програмних засобів, які використовуються 
для автоматизації управління деякої частини їх бізнес-процесів. Тому перед керівником завжди стоїть питання вибору програмного продукту 3 таким функціоналом, який автоматизує більшість процесів підприємства і максимально підвищить ефективність їх управління. Функціонал обраного продукту повинен включати сучасні методи аналізу та обробки даних, прогнозування, планування та інтелектуальної візуалізації отриманих результатів для того щоб керівник міг скористатися максимально корисною інформацію, яка буде основою побудови майбутніх стратегій розвитку виробництва. Як найбільш важливу складову діяльності підприємства виділяють дослідження процесів збуту та планування виробництва. Результати цього дослідження мають велике значення для виявлення шляхів підвищення його конкурентоспроможності на ринку. Тому розробка ефективних алгоритмів управління в програмних додатках класу систем підтримки прийняття рішень, які базуються на вирішені задач прогнозування, є досить актуальною.

Було проаналізовано ряд сучасних програмних продуктів, в яких заявлені можливості вирішення задач прогнозування збуту та планування виробництва: «MarketingExpert», «Konsi-ForExSal», «Kacaтка», «GoodsForecast.Planning», «СВТ», «АУК на основі ММП» та інші[1]. «MarketingExреrt» має «широкий» функціонал, але його основне призначення зосереджено тільки на цих двох функціях:1) проведення аудиту маркетингу (оцінка реального положення компанії на ринку, порівняння с конкурентами, виявлення сильних та слабих сторін підприємства); 2) планування маркетингу (GAP-аналіз, сегментний аналіз, SWOT-аналіз, Рortfolio-аналіз іт.д.). Крім того, користувачі скаржаться на «невдалий» та важкий інтерфейс. «Konsi-ForExSal» створений для рішення задач прогнозування, але його функціонал не містить можливостей обробки результатів прогнозу та планування виробництва. «Касатка» має «вузько» направлений функціонал, який не вирішує задач прогнозування збуту та планування виробництва остаточно.«GoodsForecast.Planning» дуже потужний, багатофункціональний, в порівнянні 3 іншими аналогами має найбільшу кількість позитивних коментарів після його використання. Але для того щоб впровадити його на підприємство необхідно мати дуже висококваліфікований персонал, який зможе їм оволодіти.«СВТ» призначений для автоматизації процесів прогнозування і планування продажів, управління виробництвом, закупками та управління ланцюгами поставок в компаніях сфер виробництва, дистрибуції та оптової торгівлі. Але при прогнозуванні використовується спрощена модель, яка дає не досить точні та ефективні прогнози. «АУК на основі ММП» реалізована в MSExcel, має «вузький» функціонал, дуже великий час обробки даних (оцінювання прогнозу відбувається 3-4 хвилини). Співробітники підприємства можуть втручатись в роботу БД, та змінювати дані під себе, що шкодить цілісності БД. Також існує велика імовірність помилок внесення нових даних.

Результатом аналізу став висновок про те, що у однієї частини продуктів, 3 дійсно широким вибором запропонованих функцій, для прогнозування працює спрощена модель, яка при використанні в реальних умовах 3 великим різноманіттям часових рядів може надавати незадовільні результати. А друга частина має скорочений функціонал і для повноцінної обробки результатів прогнозу потребує допомоги додаткових програмних засобів.

\section{Мета дослідження}

Створити ефективний алгоритм побудови моделей прогнозування збуту хлібобулочних виробів, який надає більш точні результати. Для досягнення цієї мети треба вирішити наступні завдання:

1) проаналізувати властивості часових рядів, які відповідають реальним продажам хлібобулочних виробів;

2) отримати залежності структури і параметрів моделей прогнозування від оцінок кореляційних функцій для досліджуваних часових рядів.

\section{Матеріали і методи}

Дані (продажі хлібобулочної продукції за минулий період), які є основою для прогнозування збуту, уявляють собою часові ряди. Часовий ряд $є$ послідовністю, взятою на рівновіддалених точках в часі, які йдуть одна за одною. Основою для вирішення задач прогнозування обрана модель ARIMA (модель Бокса-Дженкінса) - інтегрована модель авторегресії (AR) та ковзного середнього (MA) [2]. Вона є розширенням моделі ARMA для нестаціонарних часових рядів. Схема іiі побудови зображена на рис.1, а загальна структура може бути представлена,як такий математичний вираз:

$$
\Delta^{\mathrm{d}} \mathrm{Y}_{\mathrm{t}}=\mathrm{c}+\sum_{\mathrm{i}=1}^{\mathrm{p}} \mathrm{a}_{\mathrm{i}} \Delta^{\mathrm{d}} \mathrm{Y}_{\mathrm{t}-\mathrm{i}}+\sum_{\mathrm{i}=1}^{\mathrm{q}} \mathrm{b}_{\mathrm{i}} \varepsilon_{\mathrm{t}-\mathrm{i}}+\varepsilon_{\mathrm{t}}
$$

де $\varepsilon_{\mathrm{t}}$ - раптова складова (білий шум); $\mathrm{c}, \mathrm{a}_{\mathrm{i}}, \mathrm{b}_{\mathrm{i}}$ - параметри моделі; $\Delta^{\mathrm{d}}$ - оператор різниці.

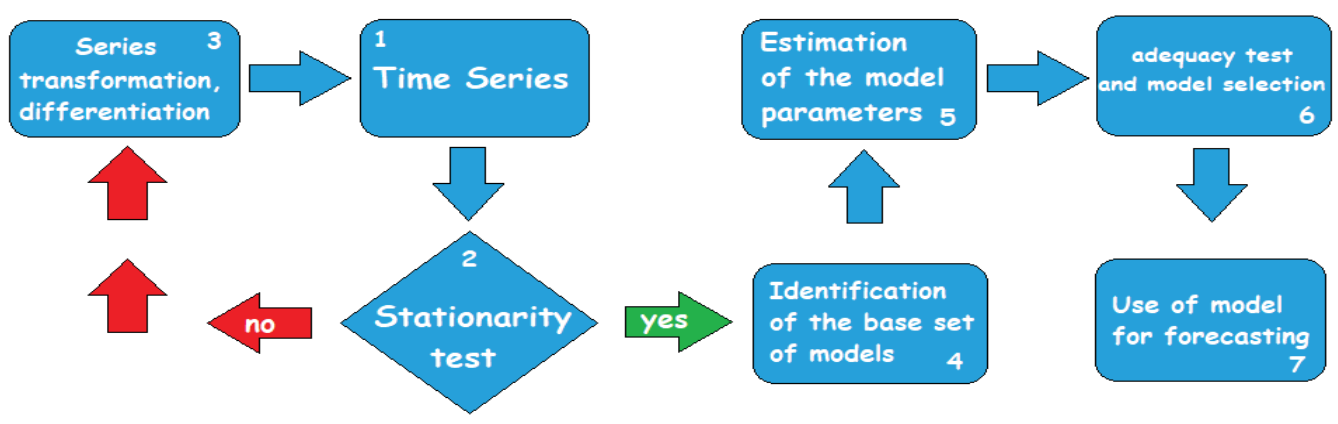

Рис. 1 - Схема побудови моделі ARIMA 
Для побудови моделей по наведеній схемі спочатку необхідно перевірити часовий ряд на стаціонарність. Це можливо за допомогою тесту Дікі-Фуллера[3],[4]. При цьому перевіряють значення параметру $\boldsymbol{a}$ авторегресійного рівняння першого порядку $\mathrm{AR}(1)$ :

$$
y_{t}=a_{1} * y_{t-1}+\varepsilon_{t} .
$$

Якщо а $=1$, то процес має одиничний корінь і ряд не є стаціонарним, а якщо а $<1$, то ряд являється стаціонарним. Якщо часовий ряд являється нестаціонарним, то наступним кроком є взяття різниць для приведення часового ряду до стаціонарного. Приклад взяття другої різниці:

$$
\Delta \mathrm{y}_{\mathrm{t}}=\mathrm{y}_{\mathrm{t}}-2 \mathrm{y}_{\mathrm{t}-1}+\mathrm{y}_{\mathrm{t}-2} \text {. }
$$

Після отримання ряду зі стаціонарними можна перейти до ідентифікації порядку моделі прогнозування. Для того щоб ідентифікувати порядок моделі ARMA, користуються методологією Бокса-Дженкінса. Головним їі елементом є дослідження коррелограмм оцінок автокореляційної функції (АКФ) та приватної автокореляційної функції (ПАКФ). Знайшовши порядок моделі відбувається розрахунок авторегресійної складової та ковзного середнього.

Для розрахунку авторегресії часового ряду, використовується вираз (якщо авторегресія другого порядку):

$$
\mathrm{y}_{\mathrm{t}}=\mathrm{a}_{1} * \mathrm{y}_{\mathrm{t}-1}+\mathrm{a}_{2} * \mathrm{y}_{\mathrm{t}-2} \text {. }
$$

При розрахунку ковзного середнього часовий ряд розглядається, як сума константи (середнього значення залишків авторегресії) та ковзного середнього між поточними та попередніми значеннями випадкових відхилень (залишків авторегресіi):

$$
\mathrm{y}_{\mathrm{t}}=\varepsilon+\left(\varepsilon_{\mathrm{t}}+\varepsilon_{\mathrm{t}-1}\right) \text {. }
$$

Остаточний розрахунок параметрів моделі реалізується за допомогою методу найменших квадратів.

Результати дослідження та їх обговорення

Для рішення задачі прогнозування запропонований алгоритм, який здійснює автоматичний підбір структури моделі та автоматичний розрахунок іiі параметрів. Він реалізується в програмному модулі 3 властивостями wеbдодатку. В якості даних для проведення досліджень була використана інформація про продажі хлібобулочних виробів на працюючому виробництві міста Одеси.

Створення адекватної моделі прогнозування на першому етапі потребує детального вивчення властивостей реальних часових рядів. Тому ці ряди необхідно описати такими моделями, які б могли надати можливість виявлення чітких відмінностей в їх параметрах. В якості інструменту для проведення порівняльного аналізу обрано додаток IDsoft[5], створений у MatLabSimulink, з моделями кореляційної функції та спектральної щільності (наведені в таблиці 1), які описуються параметрами: математичне очікування $\boldsymbol{M}$, середньоквадратичне відхилення $\boldsymbol{G}$, коефіцієнт спаду $\boldsymbol{\alpha}$ і коефіцієнт коливання $\boldsymbol{\beta}$.

Таблиця 1 - Моделі кореляційної функції та спектральної щільності

\begin{tabular}{|c|c|c|}
\hline № & Кореляційна функція & Спектральна щільність \\
\hline 1 & $R_{x}\left(\tau_{k}\right)=D_{x} e^{-\alpha\left|\tau_{k}\right|}$ & $S_{x}(\omega)=\frac{D_{x} 2 \alpha}{\omega^{2}+\alpha^{2}}$ \\
\hline 2 & $R_{x}\left(\tau_{k}\right)=D_{x} e^{-\alpha\left|\tau_{k}\right|}\left(1-\alpha\left|\tau_{k}\right|\right)$ & $S_{x}(\omega)=\frac{D_{x} 4 \alpha \omega^{2}}{\left(\omega^{2}+\alpha^{2}\right)^{2}}$ \\
\hline 3 & $R_{x}\left(\tau_{k}\right)=D_{x} e^{-\alpha\left|\tau_{k}\right|}\left(1+\alpha\left|\tau_{k}\right|\right)$ & $S_{x}(\omega)=\frac{D_{x} 4 \alpha^{3}}{\left(\omega^{2}+\alpha^{2}\right)^{2}}$ \\
\hline 4 & $R_{x}\left(\tau_{k}\right)=D_{x} e^{-\alpha\left|\tau_{k}\right|} \cos \left(\beta\left|\tau_{k}\right|\right)$ & $S_{x}(\omega)=\frac{D_{x} 2 \alpha\left(\omega^{2}+\alpha^{2}+\beta^{2}\right)}{\left(\omega^{2}-\beta^{2}-\alpha^{2}\right)^{2}+4 \alpha^{2} \omega^{2}}$ \\
\hline 5 & $R_{x}\left(\tau_{k}\right)=D_{x} e^{-\alpha\left|\tau_{k}\right|}\left(\cos \left(\beta\left|\tau_{k}\right|\right)+\frac{\alpha}{\beta} \sin \left(\beta\left|\tau_{k}\right|\right)\right)$ & $S_{x}(\omega)=\frac{D_{x} 4 \alpha\left(\alpha^{2}+\beta^{2}\right)}{\left(\omega^{2}-\beta^{2}-\alpha^{2}\right)^{2}+4 \alpha^{2} \omega^{2}}$ \\
\hline 6 & $R_{x}\left(\tau_{k}\right)=D_{x} e^{-\alpha\left|\tau_{k}\right|}\left(\cos \left(\beta\left|\tau_{k}\right|\right)-\frac{\alpha}{\beta} \sin \left(\beta\left|\tau_{k}\right|\right)\right)$ & $S_{x}(\omega)=\frac{D_{x} 4 \alpha \omega^{2}}{\left(\omega^{2}-\beta^{2}-\alpha^{2}\right)^{2}+4 \alpha^{2} \omega^{2}}$ \\
\hline
\end{tabular}

Отже на завершенні першого етапу були отримані результати ідентифікації значної кількості часових рядів, що є характерними для продажів різноманітної продукції хлібозаводу (рис.2). В тих рядах, що не відповідали властивостям 
стаціонарних, було проведено їх попереднє диференціювання. Якщо для отриманих моделей (рис.2), по їх параметрам, провести автоматичну класифікацію(кластеризацію), то можна виявити групи зі схожими властивостями. I саме по цим групам створювати відповідні прогнозні моделі.

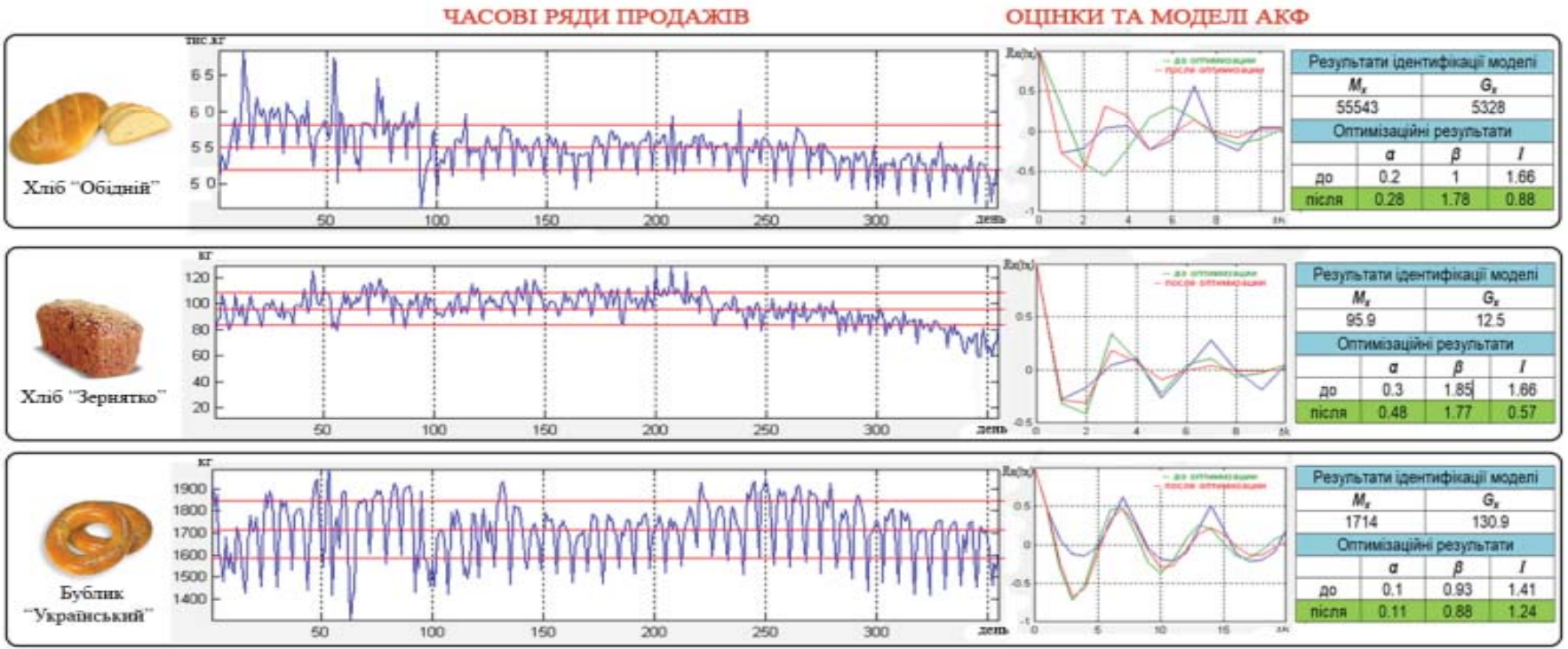

Рис. 2 - Результати ідентифікації часових рядів

Для проведення кластерного аналізу був обраний програмний модуль «Zhy\&Bor» [6]. Він реалізує процедуру вдосконаленої кластеризації даних на основі методу k-means, а його відмінною рисою стали алгоритми автоматичного розрахунку кількості кластерів та визначення положень початкових центрів кластерів (центроїдів) (рис.3).Властивості кластерів повинні забезпечити вибір варіанту структури моделі прогнозування (в першу чергу іiі порядок). Далі за характеристиками АКФ та ПАКФ розраховуються початкові значення параметрів моделі ARIMA, а потім виконується процедура їх оптимального підбору [7]. Реалізація автоматичного розрахунку параметрів моделі можлива завдяки результатам ідентифікації властивостей часових рядів і кластеризації.

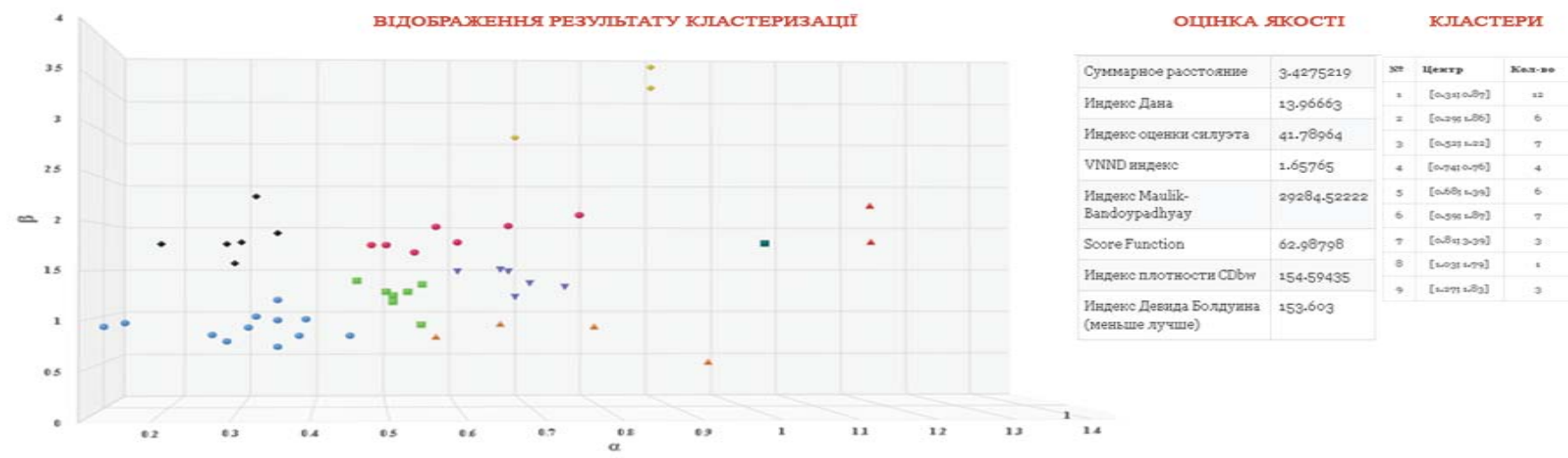

Рис. 3 - Результат кластеризації

В програмному модулі міститься стартова сторінка з вибором даних для проведення прогнозу (назва продукції для якої будується прогноз, період прогнозу). Після вибору продукції, дані продажів продукції, що вивчається, відображаються на графіку. Також надається інформація по інтервалу часу $\boldsymbol{T}$, кроку $\boldsymbol{t}$ та кількості точок відображених на графіку $\boldsymbol{N}$. На даному етапі відбувається перевірка часового ряду на стаціонарність за допомогою тесту ДікіФуллера. Результати перевірки на стаціонарність та оцінювання параметрів часового ряду наведені на рис.4. 

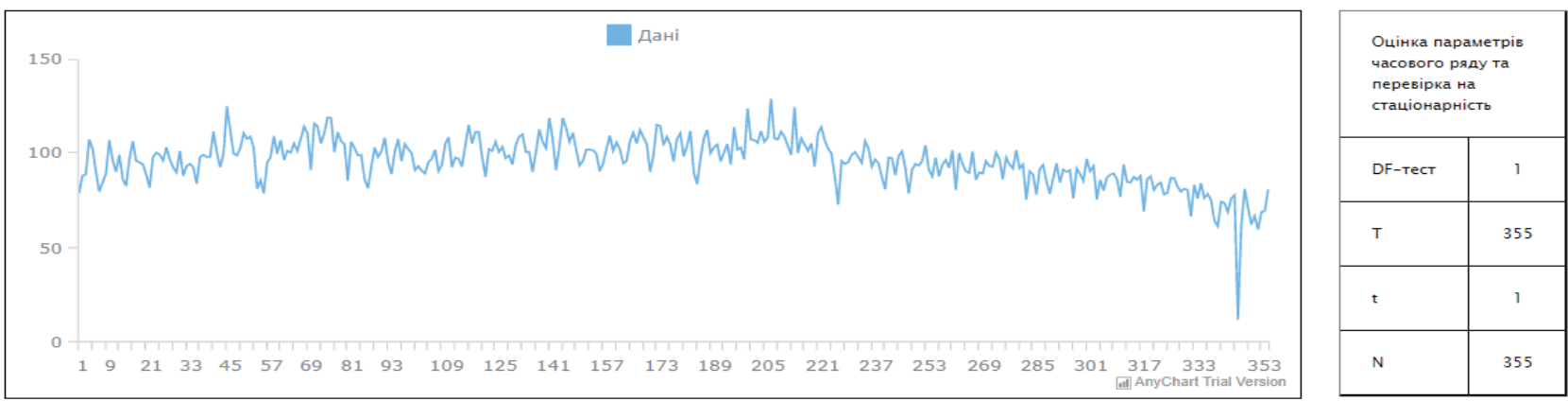

Рис. 4 - Відображення часового ряду, його параметрів та результату перевірки на стаціонарність

Якщо DF-тест дорівнює 1, то виконується операція диференціювання (рис.5) та відображаються додаткові оцінки параметрів часового ряду: $\boldsymbol{M} \boldsymbol{x}$ - математичне очікування, $\boldsymbol{D} \boldsymbol{x}$ - дисперсія, $\boldsymbol{G} \boldsymbol{x}$ - середньоквадратичне відхилення.

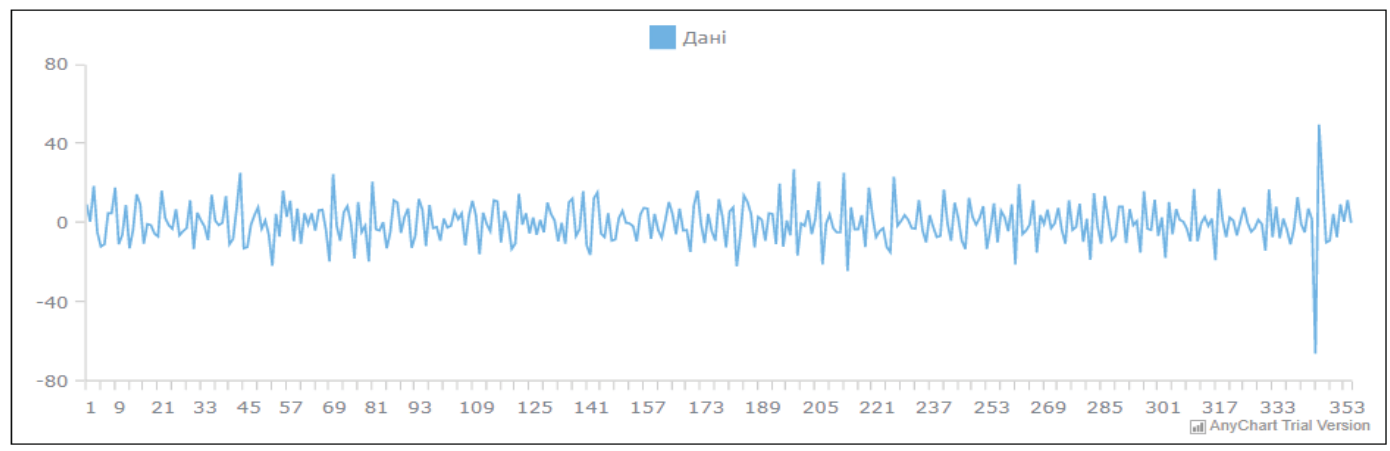

\begin{tabular}{|c|c|}
\hline \multicolumn{2}{|c|}{$\begin{array}{l}\text { Оцінка параметрів } \\
\text { часового ряду }\end{array}$} \\
\hline $\mathrm{T}$ & 354 \\
\hline $\mathrm{t}$ & 1 \\
\hline $\mathrm{N}$ & 354 \\
\hline$M x$ & -0.02 \\
\hline $\mathrm{Dx}$ & 106.55 \\
\hline$G_{x}$ & 10.32 \\
\hline
\end{tabular}

Рис. 5 - Часовий ряд після операції диференціювання та оцінки параметрів часового ряду

Після відбувається розрахунок АКФ та ПАКФ. Коррелограмми для деяких видів продукції представлені на рис. 6.Аналізуючи отримані коррелограмми АКФ та ПАКФ і опираючись на поради по вибору моделей [7] програмний модуль будує моделі прогнозування під кожний процес. Для продукції «Зернятко» коефіцієнт ПАКФ на другому лагу $\epsilon$ значимим, на третьому практично дорівнює нулю. Це говорить про те що складова AR = 2, а коефіцієнт АКФ має майже синусоїдальну форму, тоді складова MA =0, повна модель прогнозування для продукції «Зернятко» (враховуючи диференціювання) має вигляд ARIMA(2,1,0).

Для продукції «Обідній» коефіцієнт ПАКФ на третьому лагу є значимим, на четвертому майже дорівнює нулю, AR $=3$, АКФ має практично синусоїдальну форму, MA = 0, повна модель ARIMA $(3,1,0)$. Для продукції «Бублик» коефіцієнт ПАКФ на другому лагу значимий, на третьому практично нуль, $\mathrm{AR}=2, \mathrm{AKФ} \mathrm{після} \mathrm{першого} \mathrm{лагу} \mathrm{падає}$ практично на нуль, МА = 1, викиди на великих лагах (більше третього) скоріше викликані сезонністю процесів, повна модель прогнозування для даної продукції $\operatorname{ARIMA}(2,1,1)$. Після ідентифікації моделі та оцінки параметрів моделі, програмний модуль будує прогноз на майбутнє (рис.7).

Програмний модуль відображає таблиці з даними минулими та отриманими при прогнозуванні, а також пропонує інформацію по затратам енергоресурсів та сировини для виготовлення продукції на прогнозований період. Дана інформація $є$ дуже важливою і корисною. За допомогою неї керівництво підприємства зможе будувати стратегії на майбутнє та ефективно управляти збутом та виробництвом.

\section{Висновки}

1. Проведений аналіз сучасних програмних продуктів, які вирішують задачі прогнозування збуту та планування виробництва, підтвердив актуальність розробки нового програмного модулю, який надає більш точні прогнози.

2. Аналіз часових рядів показав наявність груп зі схожими ознаками по кореляційним характеристикам.

3. Результати кластерного аналізу сприяли розробці алгоритму, суть якого полягає в автоматичній побудові структури моделі прогнозування та автоматичному розрахунку ії параметрів. 

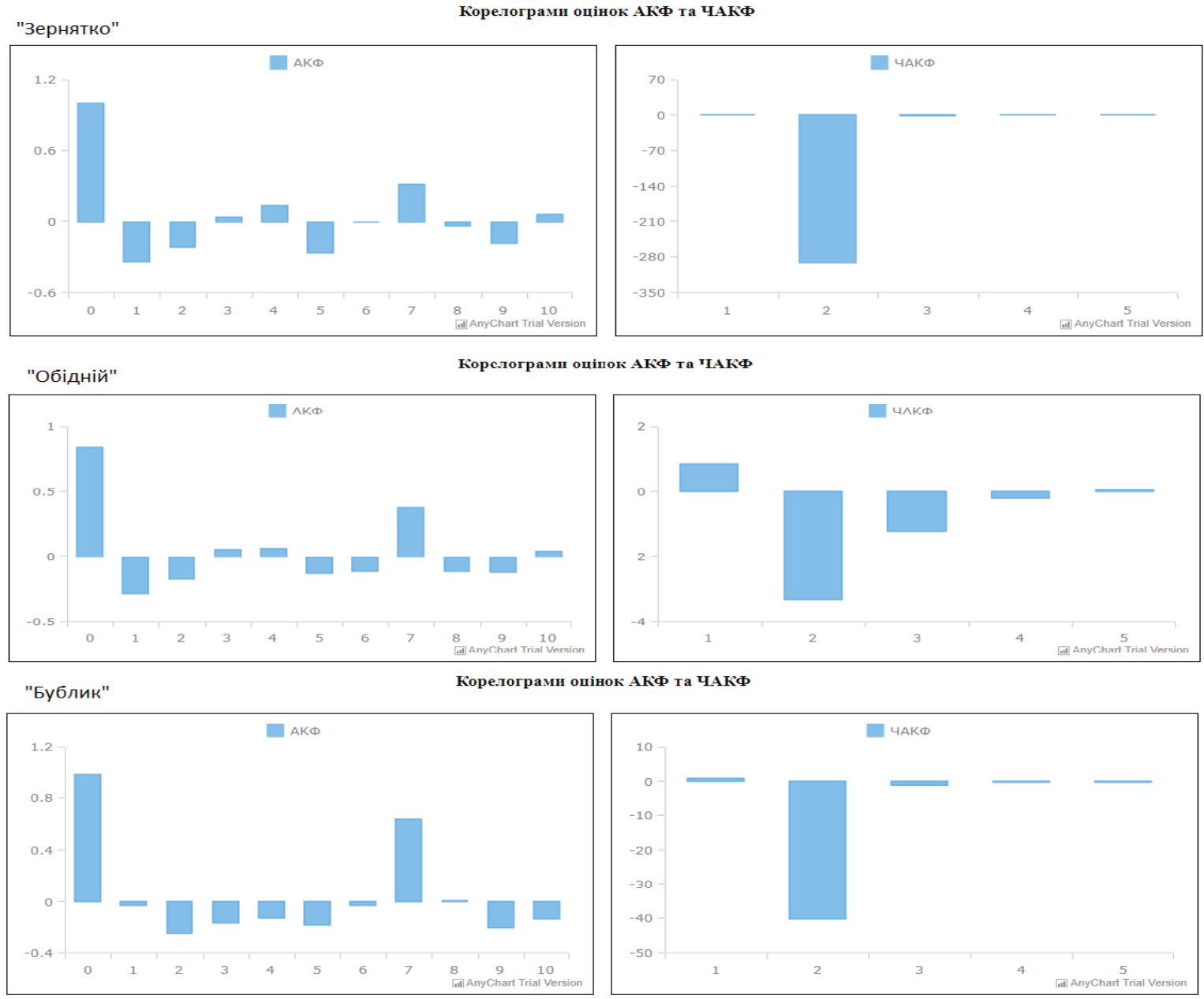

Рис. 6 - Коррелограмми оцінок АКФ та ПАКФ для продукції «Зернятко», «Обідній», «Бублик»

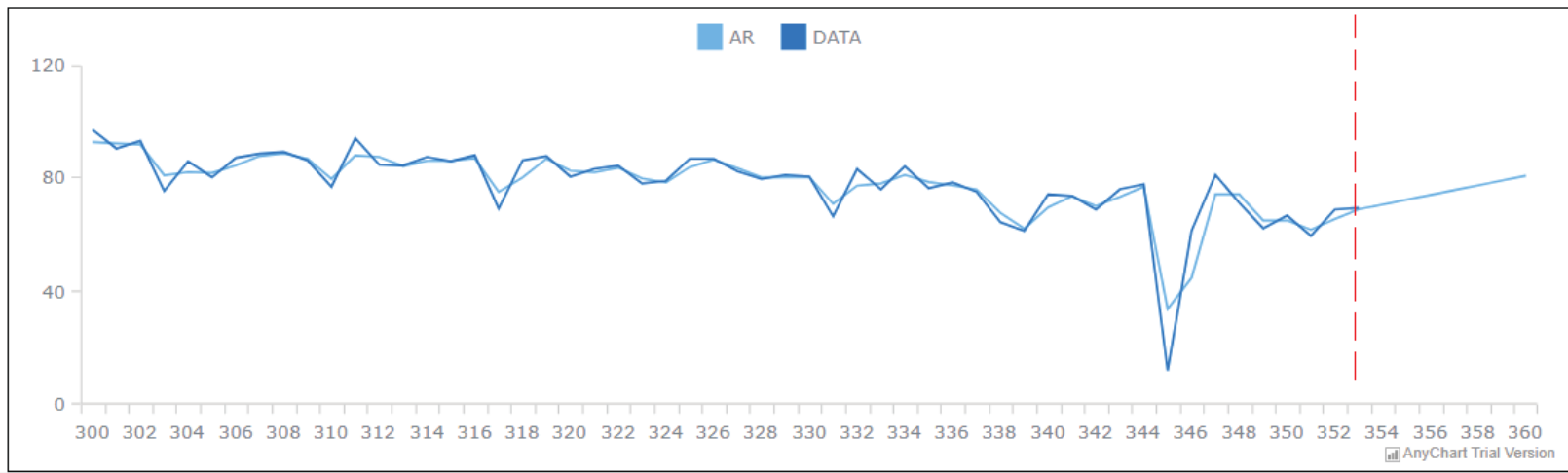

Рис. 7 - Прогноз продажів продукції на 7 днів

\section{Література}

[1] Характеристика ринку маркетингового забезпечення. URL: https://studopedia.info/5-55827.html (дата звернення: 10.03.2019).

[2] Бокс Дж., Дженкинс Г. Анализ временних рядов, прогнозирование и управление: учебник 1 вип. Москва: Мир, 2006. $408 \mathrm{c}$.

[3] Магнус Я. Р., Катышев П. К., Пересецкий А. А. Эконометрика: учебник. Москва: Дело, 2007. 504 с.

[4] Крук Д.М., Лукин В.С., Мосин Е.А. Основы экономического и социального прогнозирования: учебник. Москва: Высшая школа, 1985. $200 \mathrm{c}$.

[5] Жигайло О.М. Особливості ефективного вирішення задачі адаптації регулятора в САУ прес-гранулятором. 
Зернові продукти і комбікорми. 2014. №1(53).С. 45-50.

[6] Жигайло О.М., Борис В.В. Кластерний аналіз даних в автоматизованих системах простежуваності. Автоматизація технологічних та бізнес-процесів. 2018. Том 10, №1. С. 39-46.

[7] Афанасьев В.Н., Юзбашев М.М. Анализ временных рядов и прогнозирование: учебник. Москва: Финансы и статистика, 2001. 228 с.

[8] Идентификация модели ARMA. URL: https://studbooks.net/1875074/ekonomika/identifikatsiya_modeli_arma (дата звернення: 15.05.2019).

\title{
References
}

[1] Harakteristika rinku marketingovogo zabezpechennya [Online]. Available: https://studopedia.info/5-55827.html. [Accessed March 10, 2019].

[2] J. Box, H. Jenkins, Analiz vremennih ryadov, prognozirovanie i upravlenie. Moscow: Mir, 2006.

[3] Y.R. Magnus, P. K. Katyishev, A.A. Peresetskiy, Ekonometrika. Moscow: Delo, 2007.

[4] D.M. Kruk, V.S. Lukin, E.A. Mosin, Osnovyi ekonomicheskogo i sotsialnogo prognozirovaniya. Moscow: Vyisshaya shkola, 1985.

[5] O.M. Zhigaylo, "Osoblivosti efektivnogo virishennya zadachi adaptatsiyi regulyatora v SAU pres-granulyatorom," Zernovi produkti i kombikormi, no.1(53), pp.45-50, 2014.

[6] O.M. Zhigaylo,V.V. Boris, "Klasterniy analiz danih v avtomatizovanih sistemah prostezhuvanosti," Avtomatizatsiya tehnologichnih ta biznes-protsesiv,vol.10, no.1, pp.39-46, 2018.

[7] V.N. Afanasev, M.M. Yuzbashev, Analiz vremennyih ryadov i prognozirovanie. Moscow: Finansyi i statistika, 2001.

[8] Identifikatsiya modeli ARMA [Online]. Available: https://studbooks.net/1875074/ekonometrika/identifikatsiya_modeli_arma. [Accessed May 15, 2019 ].

УДК 004.4'24:378.091.214 (083.17)

\section{ANALYSIS OF PROCESS CREATION OF THE COURSES TIMETABLING}

\author{
Sakaliuk O. ${ }^{1}$, Trishyn F. ${ }^{2}$ \\ ${ }^{1,2}$ Odessa National Academy of Food Technologies, Odessa, Ukraine \\ ORCID: ${ }^{1}$ https://orcid.org/0000-0002-5051-518X, ${ }^{2}$ https://orcid.org/0000-0001-5994-3538 \\ E-mail: ${ }^{1}$ sakaliuk.olexiy@gmail.com, ${ }^{2}$ fatrishyn@gmail.com
}

Copyright (C) 2018 by author and the journal "Automation technologies and business - processes. This work is licensed under the Creative Commons Attribution International License (CC BY). http://creativecommons.org/licanses/by/4.0

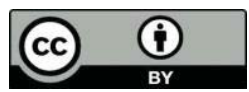

ONAFT

Open Access

DOI:

Анотація: Організація навчання здобувачів освіти, здійснюється відповідно до розкладу занять. Розклад занять має забезпечити ефективне виконання навчального плану в повному обсязі.

Питанням формування розкладу навчальних занять приділялася достатня увага протягом останніх десятиліть. Але навіть і сьогодні прочес формування розкладу навчальних занять вимагає достатньо велику частину людського керування. Типова проблема розкладу занять полягає в плануванні набору зустрічей між викладачами і студентами протягом певного періоду часу, щзо потребує певних ресурсів і повинно відповідати деяким додатковим вимогам. Суттєвими вимогами при складанні розкладу є такі, в яких викладач, студент або аудиторія не використовуються більше одного разу в один часовий інтервал. Складання розкладу в закладах вищої освіти виконується кожен семестр. Підготовка розкладу є трудомістким, стомлюючим прочесом, щзо вимагає значну кількість людських ресурсів та часу. 